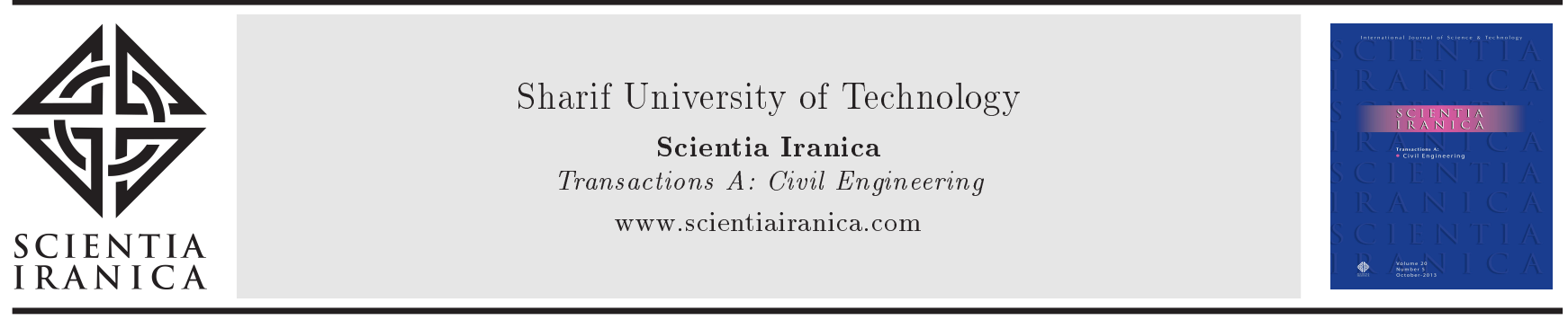

\title{
The effect of inadequate compaction on compressive strength of concrete exposed to elevated temperature
}

\author{
T. Gonen* \\ Department of Civil Engineering, Faculty of Engineering, Usak University, 64200, Usak, Turkey.
}

Received 9 August 2014; received in revised form 25 January 2015; accepted 9 May 2015

\section{KEYWORDS}

Inadequate

compacting;

Taguchi method;

ANOVA;

High temperature;

Compressive strength.

\begin{abstract}
One of the important factors affecting the quality of concrete is the placement of fresh concrete inside the formwork. Inadequate compaction is a common problem in concrete technology. In this study, the effect of inadequate compaction on compressive strength and ultrasonic pulse velocity of concrete exposed to elevated temperature is examined. For this purpose, various compaction rates were applied during the casting stage of concrete in order to simulate various levels of inadequate compaction. Four different water-cement ratios $(0.50,0.40,0.38$, and 0.35$)$ were selected. All concrete specimens were exposed to 450 or $900^{\circ} \mathrm{C}$ for one hour. The Taguchi approach was used to reduce the number of samples. The results were evaluated by the Analysis of Variance (ANOVA) method. Test results showed that inadequate compaction played a significant role, more than curing time, in the compressive strength after high temperature exposure.
\end{abstract}

(C) 2016 Sharif University of Technology. All rights reserved.

\section{Introduction}

Concrete is a composite material having porous, composed of mineral aggregates in a cement matrix. The hydration reaction of cement occur a solid porous system. The porous system of concrete allows transport of water and other substances [1]. The pores of concrete are classified according to their size as air pores, capillary pores, gel pores, and compaction pores (affect durability) $[2,3]$. The gel pores, which are mostly $1.5-2.0 \mathrm{~nm}$ in size, do not influence negatively the strength of concrete. The role of these pores is to directly affect creep and shrinkage. On the other hand, capillary, air, and compaction pores are responsible for reductions in compressive strength and the Young's or elasticity modulus [4-8].

Concretes with higher water-to-cement ratios naturally contain more water than what is required for complete hydration of cement. This excess water

\footnotetext{
*. Tel.: +902762212121; Fax: +902762212137

E-mail address: tahir.gonen@usak.edu.tr
}

causes voids known as capillary pores. Pores in concrete can also occur by inadequate compaction caused by poor workmanship (see Figure 1). This pore system is one of the most important properties of concrete because of its effects on carbonation and sorptivity [9].

High temperature is known to cause durability problems in concrete. Even though concrete is a noncombustible material, its internal structure deteriorates at high temperature. The type of present pores plays an important role in durability. Generally, low porosity with dense microstructure is probably essential to obtain good resistance to several factors, such as chloride, sulphate, etc. However, a dense microstructure seems to be a disadvantage when exposed to fire. For instance, a great difference may exist between the properties of high performance concrete and normal concrete after being subjected to elevated temperature [10-12]. Because the porosity of high performance concrete is low and its structure is dense, its performance at high temperature is lower than that for the normal strength concrete [13]. Of course, the level of desiccation of high strength concrete 


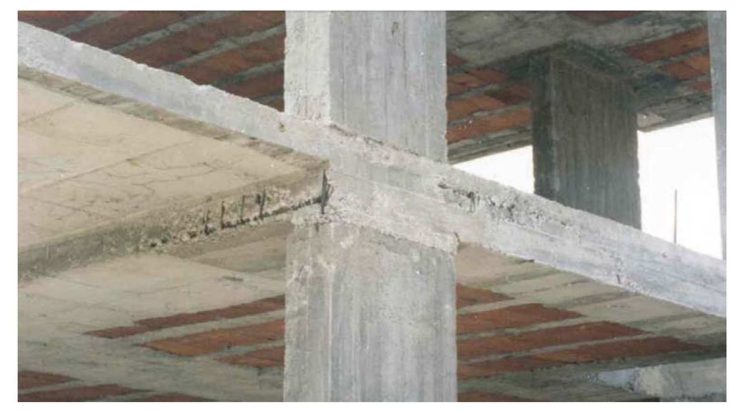

a) Inadequate compaction at the beam-column joints

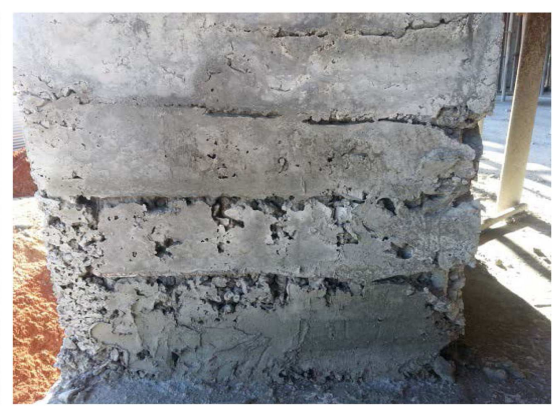

b) Inadequate compaction at the bottom of column

Figure 1. Concrete defects resulting from inadequate compaction.

Table 1. The chemical properties of the Portland cement.

\begin{tabular}{|c|c|c|c|c|c|c|c|c|c|}
\hline \multicolumn{10}{|c|}{ Chemical analysis (\% by mass) } \\
\hline $\mathrm{SiO}_{2}$ & $\mathrm{Al}_{2} \mathrm{O}_{3}$ & $\mathrm{Fe}_{2} \mathrm{O}_{3}$ & $\mathrm{CaO}$ & $\mathrm{MgO}$ & $\mathrm{SO}_{3}$ & $\begin{array}{c}\text { Ignition } \\
\text { loss }\end{array}$ & $\begin{array}{c}\text { Insoluble } \\
\text { residue }\end{array}$ & $\mathrm{Cl}^{-}$ & \\
\hline 26.86 & 8.09 & 5.18 & 45.88 & 3.64 & 2.41 & 2.95 & 4.99 & 0.01 & \\
\hline \multicolumn{10}{|c|}{ Physical analysis } \\
\hline \multirow{2}{*}{$\begin{array}{l}45 \mu \\
(\%)\end{array}$} & \multirow{2}{*}{$\begin{array}{c}\text { Blaine } \\
\left(\mathrm{cm}^{2} / \mathrm{g}\right)\end{array}$} & \multirow{2}{*}{$\begin{array}{l}\text { Initial } \\
\text { setting } \\
\text { (hour) }\end{array}$} & \multirow{2}{*}{$\begin{array}{c}\text { Final } \\
\text { setting } \\
\text { (hour) }\end{array}$} & \multirow{2}{*}{$\begin{array}{l}\text { Specific } \\
\text { gravity } \\
\left(\mathrm{g} / \mathbf{c m}^{3}\right)\end{array}$} & \multirow{2}{*}{$\begin{array}{l}\text { Density } \\
\left(\mathrm{g} / \mathrm{cm}^{\mathbf{3}}\right)\end{array}$} & Increase & \multicolumn{3}{|c|}{ Compressive strength } \\
\hline & & & & & & $\begin{array}{c}\text { in volume } \\
(\%)\end{array}$ & $\begin{array}{c}2 \text { days } \\
\left(\mathrm{N} / \mathrm{mm}^{2}\right)\end{array}$ & $\begin{array}{c}7 \text { days } \\
\left(\mathrm{N} / \mathrm{mm}^{2}\right)\end{array}$ & $\begin{array}{c}28 \text { days } \\
\left(\mathrm{N} / \mathrm{mm}^{2}\right)\end{array}$ \\
\hline 1.9 & 4326 & $02: 35$ & 03:45 & 2.98 & 2.92 & 4 & 16.9 & 28.4 & 39.0 \\
\hline
\end{tabular}

exposed to high temperature is related to its humidity.

There has been much research on the properties of normal and high performance concretes subjected to high temperatures [14-17]. However, no study on the behavior of inadequately compacted concrete at elevated temperature has been performed. This study was performed to ascertain the influence of inadequate compaction on compressive strength and ultrasonic pulse velocity of concretes exposed to elevated temperature. The Taguchi method was generally used to reduce the number of required experiments and to determine the optimum conditions. Furthermore, ANOVA tests were performed to statistically evaluate the major process parameters and their contributions to the compressive strength of the concrete.

\section{Materials and methods}

\subsection{Materials}

Tap water was used as concrete mixing water in all test specimens. The aggregate, river gravel and sand, commonly used in concrete production, were used (max. size of aggregate $=16 \mathrm{~mm})$. Water absorption and density values of the aggregate were $3.5 \%$ and $2.75 \mathrm{~g} / \mathrm{cm}^{3}$, respectively. The cement used in this study was CEM I $42.5 \mathrm{~N}$ according to TS EN 197-1 (Turkish standard) [18]. The chemical compositions (as percentage by mass of the constituent oxides), the mechanical and some physical properties of the CEMI 42.5 were presented in Table 1.

\subsection{Mix design and Taguchi method}

One of the most important stages in the design of experiments is selection of the controlling factors. The controlling factors should be included so to make it possible to identify non-significant variables at the earliest opportunity [19]. The Taguchi method is a statistical method developed by Genichi Taguchi as an optimization technique [20]. According to Taguchi method, the performance of a specimen tested may be affected by both environmental conditions and components. Taguchi's method supplies parameter design to researchers with a systematic and efficient method for determining near optimum design parameters for both performance and cost [21,22].

The compressive strength will mainly depend on the manufacturing conditions employed. Table 2 shows the variables considered in the experiment. Concretes were characterized by different water/cement contents of $0.35,0.38,0.40$, and 0.50 . The concretes were prepared by four different compacting techniques to create various levels of compaction porosity. In addition, two curing times were examined, 7 and 28 days. All mixes included $400 \mathrm{~kg} / \mathrm{m}^{3}$ of cement. Experimental parameters and variables measured, which were determined in initial tests, are summarized in Table 2. In this optimization, four levels and three parameters were 
Table 2. Controllable factors and their variation levels.

\begin{tabular}{lccc}
\hline Factor & $\begin{array}{c}\text { Water/cement } \\
\boldsymbol{A}\end{array}$ & $\begin{array}{c}\text { Compacting } \\
\text { type } \\
\boldsymbol{B}\end{array}$ & $\begin{array}{c}\text { Curing } \\
\text { time } \\
\boldsymbol{C}\end{array}$ \\
\hline Level 1 & 0.50 & Vibration table & 7 \\
Level 2 & 0.40 & 25 times by spading & 28 \\
Level 3 & 0.38 & 15 times by spading \\
Level 4 & 0.35 & Non-compacted \\
\hline
\end{tabular}

taken based on a L16 orthogonal array according to Taguchi design (Table 3 ).

In Table 3 , it should be noticed that parameter $A$ (i.e., water/cement ratio) has four levels: A1 (i.e., 0.50), A2 (i.e., 0.40), A3 (i.e., 0.38), and A4 (i.e., $0.35)$. Parameters $B$ and $C$ are compaction type and curing time, respectively. All test of concrete samples was repeated three times under the same laboratory conditions to observe the effect of variability on the physical and mechanical properties studied.

As previously emphasized, the compressive strengths of concrete samples were measured at elevated temperature. Signal to noise rate was chosen as the optimization criterion. Signal to noise rate for "the larger the better" situation for compressive strength was evaluated by utilizing Eq. (1) (see Ref. [23]):

$$
S / N=-10 \times \log _{10}\left[\frac{1}{n} \sum_{i=1}^{n} \frac{1}{Y_{i}^{2}}\right] .
$$

Lower porosity gives better performance. For this reason, the "smaller is better (LB)" for porosity parameter was used to find the optimal experimental conditions (Eq. (2)) [23], where $S / N$ (Signal/Noise) is performance statistics, $Y_{i}$ is the performance value of $i$ th experiment, and $n$ is the number of recurrence done for an experimental combination. In the Taguchi approach, the experiment corresponding to optimum experiment conditions may not be done during the whole period of experimentation. In such cases, the signal to noise rate corresponding to optimum studying conditions can be estimated by using the balanced characteristic of orthogonal array [24].

$$
S / N=-10 \times \log _{10}\left[\frac{1}{n} \sum_{i=1}^{n}\left(Y_{i}-Y_{0}\right)^{2}\right] .
$$

\subsection{Specimen preparation and curing}

The concretes were prepared in the laboratory using a pan type mixer with 56 liters of capacity. The mixture proportions were calculated by the absolute volume method. $100 \mathrm{~mm}$ cubic molds were used to place fresh concrete. Fresh concrete was placed into the mold by a compacting bar or vibration table. The compacting bar was a $3800 \mathrm{~mm}$ long steel bar, a $25 \mathrm{~mm}$ square end for ramming with $1.8 \mathrm{~kg}$ weighing. Various levels of compaction porosity (poor, medium, high) were created with different compaction techniques during the casting process. These techniques involved vibration or 25 tamps per layer (double layer $50 \mathrm{~mm}$ ) for good

\begin{tabular}{|c|c|c|c|c|c|c|c|c|}
\hline \multirow[t]{2}{*}{$\begin{array}{l}\text { Exp. } \\
\text { no }\end{array}$} & \multicolumn{3}{|c|}{$\begin{array}{l}\text { Parameters } \\
\text { and } \\
\text { their levels }\end{array}$} & \multirow[t]{2}{*}{$\begin{array}{l}\text { Porosity } \\
(\%)\end{array}$} & \multicolumn{4}{|c|}{$\begin{array}{c}\text { Compressive strength } \\
(\mathrm{MPa})\end{array}$} \\
\hline & $A$ & $B$ & $C$ & & $20^{\circ} \mathrm{C}$ & $450^{\circ} \mathrm{C}$ & $650^{\circ} \mathrm{C}$ & $900^{\circ} \mathrm{C}$ \\
\hline M1 & 1 & 1 & 1 & 14.4 & 52.0 & 38.0 & 33.6 & 15.4 \\
\hline M2 & 1 & 2 & 2 & 14.6 & 49.6 & 37.8 & 32.8 & 12.7 \\
\hline M3 & 1 & 3 & 2 & 15.0 & 60.7 & 45.9 & 36.5 & 15.9 \\
\hline M4 & 1 & 4 & 2 & 15.5 & 55.3 & 33.5 & 31.7 & 10.5 \\
\hline M5 & 2 & 1 & 1 & 13.9 & 63.2 & 58.1 & 48.5 & 26.9 \\
\hline M6 & 2 & 2 & 1 & 14.3 & 61.5 & 58.0 & 43.5 & 19.7 \\
\hline M7 & 2 & 3 & 2 & 14.8 & 57.7 & 48.3 & 35.7 & 12.3 \\
\hline M8 & 2 & 4 & 2 & 15.3 & 54.6 & 40.3 & 33.5 & 10.4 \\
\hline M9 & 3 & 1 & 2 & 9.2 & 95.4 & 88.4 & 52.1 & 19.3 \\
\hline M10 & 3 & 2 & 2 & 11.0 & 91.4 & 85.6 & 51.2 & 23.2 \\
\hline M11 & 3 & 3 & 1 & 12.3 & 80.3 & 65.4 & 41.0 & 17.9 \\
\hline M12 & 3 & 4 & 1 & 13.5 & 73.2 & 58.6 & 36.4 & 13.4 \\
\hline M13 & 4 & 1 & 2 & 9.8 & 97.2 & 81.1 & 49.4 & 24.1 \\
\hline M14 & 4 & 2 & 2 & 10.4 & 94.7 & 88.2 & 60.5 & 30.9 \\
\hline M15 & 4 & 3 & 1 & 11.6 & 85.5 & 79.6 & 46.9 & 22.9 \\
\hline M16 & 4 & 4 & 1 & 12.5 & 74.5 & 56.4 & 37.4 & 14.1 \\
\hline
\end{tabular}

Table 3. The chosen $L_{16}$ experimental plan and results. 
compaction (VC and 25C, respectively), 15 tamps per layer (double layer $50 \mathrm{~mm}$ ) for medium compaction (15C), and Non-Compacted (NC) for poor compaction. Concrete specimens with various rates of compaction were kept for $24 \mathrm{~h}$ in laboratory conditions and then cured for a period of 7 or 28 days in water saturated by lime.

\subsection{Compressive strength and ultrasound}

Compressive strengths were determined on $100 \mathrm{~mm}$ cubic specimens at elevated temperatures. Compressive strength tests were applied to control samples and samples were exposed to elevated temperature with $3000 \mathrm{kN}$ hydraulic load controlled by a digital display press.

The transit time of a pulse between transducers placed on the surfaces of a concrete structure is measured by means of ultrasonic pulse velocity equipment. The pulse velocity can be calculated using the measured path length through the concrete. Since ultrasonic tests are affected by the humidity of the concrete, specimens were dried in an oven before tests. Wave speed was calculated with Eq. (3).

$$
V=(h / t)^{*} 10^{6},
$$

where $V$ is supersonic wave speed $(\mathrm{m} / \mathrm{sec}), t$ represents the time between transmission and reception ( $\mu$ sn), and $h$ is the measuring distance between the surfaces of concrete specimens $(\mathrm{m})$.

\subsection{Apparent porosity}

$100 \mathrm{~mm}$ cubic specimens were prepared for porosity tests. Oven dried $\left(W_{\text {dry }}\right)$, saturated dried surface ( $\left.W_{\text {sat }}\right)$, and underwater weight $\left(W_{\text {wat }}\right)$ of these specimens were determined and porosity values of the specimens were found according to Eq. (4) [25-27].

$$
P=\frac{\left(W_{\mathrm{sat}}-W_{\mathrm{dry}}\right)}{\left(W_{\mathrm{sat}}-W_{\mathrm{wat}}\right)} 100 .
$$

\subsection{High temperature}

Specimens with various compacting and water-cement ratios were air dried for 7 days at an average temperature of $20^{\circ} \mathrm{C}$ and relative humidity of $30 \pm 10 \%$ before exposure to high temperatures. After drying, the three specimens from each group were heated to 450 , 650 , or $900^{\circ} \mathrm{C}$ at a $6^{\circ} \mathrm{C} / \mathrm{min}$ heating rate, while the control specimens were kept at laboratory temperature. Each temperature reached was maintained for $1 \mathrm{~h} \mathrm{[28].}$ Heating-cooling procedures were three stages. Firstly, specimens were heated to the specified temperature level without loading. Then, the specimens were kept for one hour at the target temperature, and finally cooled to room temperature, and then subjected to testing [29].

\section{Results and discussion}

The aim of this study was to determine the effects of inadequate compaction of concrete on compressive strength exposed to elevated temperature by means of the Taguchi method. Statistically significant and percent contributions of the factors, measured on the strength and porosity properties of concrete samples, were evaluated by using ANOVA.

Taguchi method clearly helped in designing this partial factorial ANOVA, which reduced the number of trials to 16 . This resulted in using less material (thus reducing cost), less space for storing the specimens while they were cured, and less time spent for preparing the samples. The best possible testing conditions for the specimens prepared by different mixing processes can be determined from the main effect in Figures 26 for porosity and compressive strength at elevated temperature. In addition, Figures 2-6 shows the relative importance of the experimental parameters on compressive strength and porosity. Figure 2 shows the variation of performance statistics with porosity parameters.

"Level 1" compaction was performed by vibration. The series corresponding to level 1 (compacting) can be seen in Table 3 (column B). The signal to noise value of the first data point is, thus, the average of the results of the experiment of porosity or compressive strength obtained from the experiments 1, 5, 9, and 13 . The experimental conditions for the second data point, thus, are the conditions of the experiments starting with number 2 in column B (i.e., experiments 2, 6, 10, and 14), and so on.
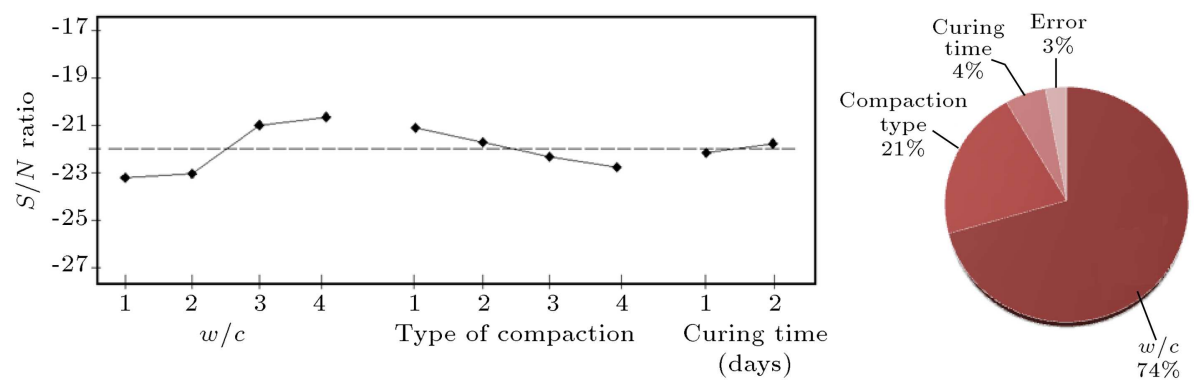

Figure 2. $S / N$ graph of factors measured and effect ratio for porosity. 

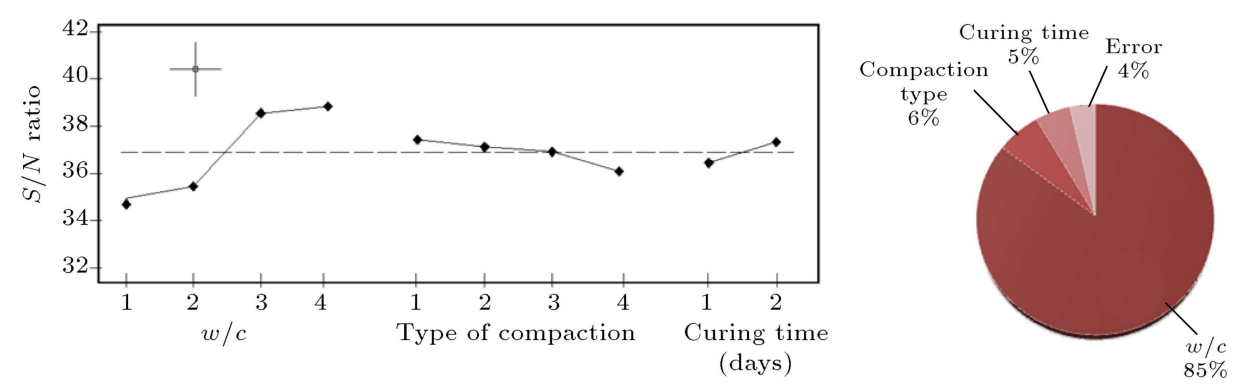

Figure 3. $S / N$ graph of factors measured and effect ratio for compressive strength at $20^{\circ} \mathrm{C}$.
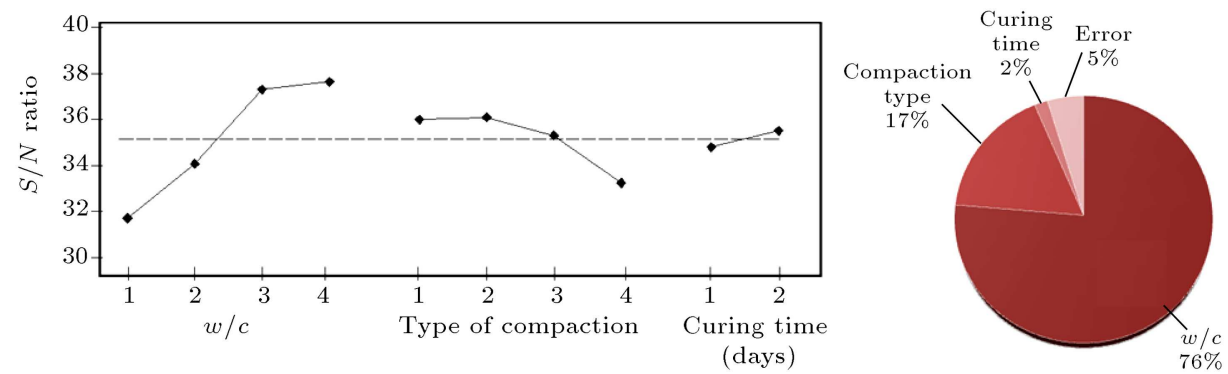

Figure 4. $S / N$ graph of factors measured and effect ratio for compressive strength at $450^{\circ} \mathrm{C}$.
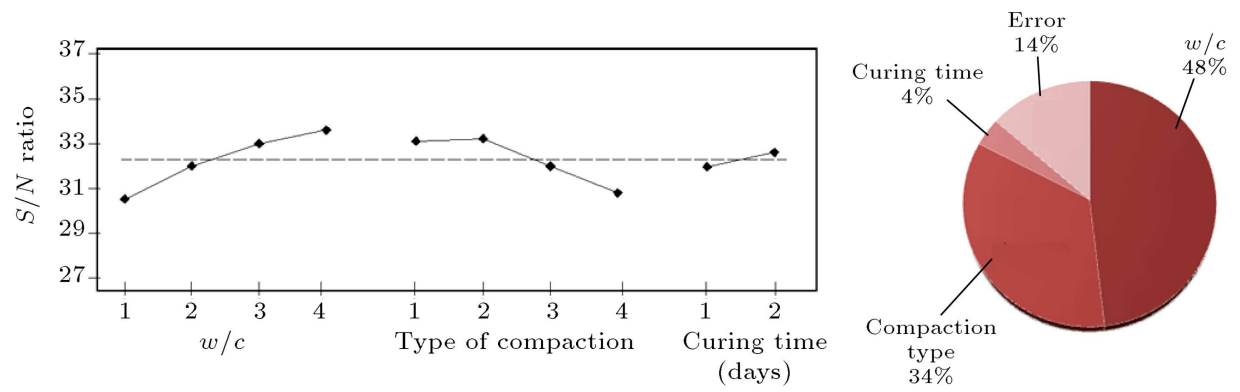

Figure 5. $S / N$ graph of factors measured and effect ratio for compressive strength at $650^{\circ} \mathrm{C}$.
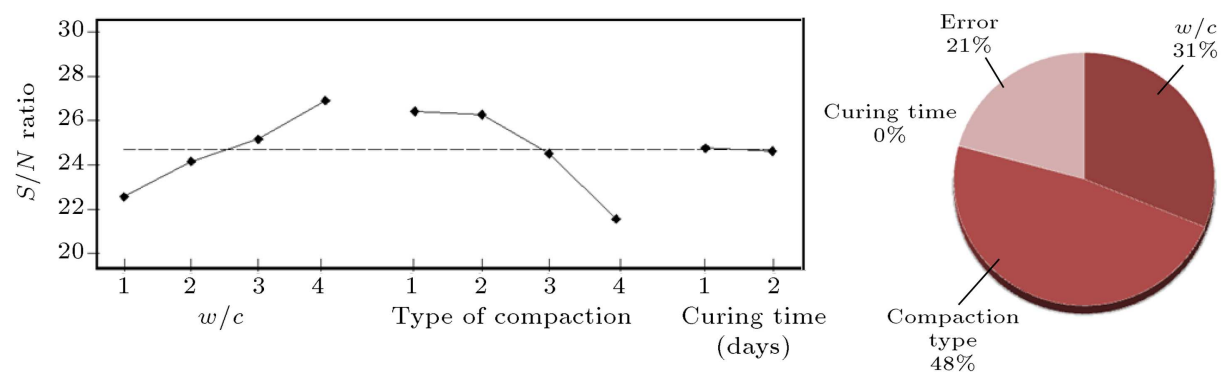

Figure 6. $S / N$ graph of factors measured and effect ratio for compressive strength at $900^{\circ} \mathrm{C}$.

Porosity increased depending on the increase in water-binder ratio. It is clearly seen that water/cement ratio was the most influential parameter, with a $74 \%$ effect on porosity of concrete specimens (Figure 2). The compacting method was the second most influential parameter, with a $21 \%$ effect on porosity. The porosity increased as water/cement increased and compaction rate decreased. The average $S / N$ ratio of all specimens was -22.164. Non-compacted and 15 tamps per layer concrete specimens were below average. The least effective parameter was curing time. A previous study [30], investigating the effects of curing conditions, water-cement ratio, and curing time on porosity, gave similar trends.

The compressive strength of concrete highly depends on the ratio of water to cement and of cement to aggregate. At the same time, it depends on degree of compaction, grading, shape, bond between mortar and aggregate, strength, and size of the aggregate [3133]. Also, the compressive strength of concrete varies inversely with $w / c$ ratio. In this study, $0.35 w / c$ ratio maximized the $S / N$ as expected (Figure 3 ). Water 
cement ratio played a role in determining compressive strength of samples cured at $20^{\circ} \mathrm{C}$ for 28 days. Other parameters, evaluated in this study, had very little effects for samples cured at $20^{\circ} \mathrm{C}$ for 28 days. The test results demonstrated that inadequate compaction caused a slight decrease in compressive strength [9].

The compressive strength of concrete decreases after it is subjected to high temperatures. Degree of decrease is dependent on material properties as well as environmental factors (such as constituents, initial strength before exposure to high temperature, moisture content $[34,35]$. The high moisture content of concrete can give rise to vapor pressure in the pores, especially in high strength concrete at high temperature and may result in explosive spalling. As the moisture content has an important role in high temperature resistance and spalling behavior of concrete, the concrete specimens were dried to a constant weight in a drying oven in this study.

Generally, compressive strength of concrete specimens decreased with increase in temperature (see Table 3 ). Figures 4-6 shows the variation of the signal to noise of parameters on the compressive strength of specimens exposed to 450,650 , and $900^{\circ} \mathrm{C}$. The best performance at all temperatures was shown by vibration compacted samples having $0.35 \mathrm{w} / \mathrm{c}$. The higher the $w / c$ ratio, the more decrease of compressive strength at all temperature levels. It was clearly shown in Figures 4-6 that the influence of compaction increased with increase in temperature, while the role played by $w / c$ ratio decreased. The best performance at all temperatures for the $0.35 \mathrm{w} / \mathrm{c}$ samples was shown by vibration compacted samples cured for 28 days. Increased water content decreased compressive strength at all temperatures (Figures 4-6). ANOVA analysis showed that both $w / c$ ratio and compaction type played significant roles in compressive strength at 650 and $900^{\circ} \mathrm{C}$.

Ultrasonic Pulse Velocity (UPV) is often used for assessing the quality of concrete and to estimate compressive strength. Ultrasonic pulse velocity has been used for a long time to estimate the physical and mechanical properties of cementitious systems. A number of relationships relating ultra-pulse velocity to concrete strength are available in the literature for self-compacting concretes [36], concretes with mineral admixtures [37], and various others [38-41]. However, errors in estimation of compressive strength using nondestructive tests can occur because of the heterogeneity of the concrete's composition, such as varied air and moisture contents [42]. The coefficient of correlation $\left(R^{2}\right)$ values indicated that the relationship between ultrasonic pulse velocity and compressive strength is low, possibly because of the concrete mixture or the elevated temperature [43]. The relationship between ultrasonic pulse velocity and compressive strength was

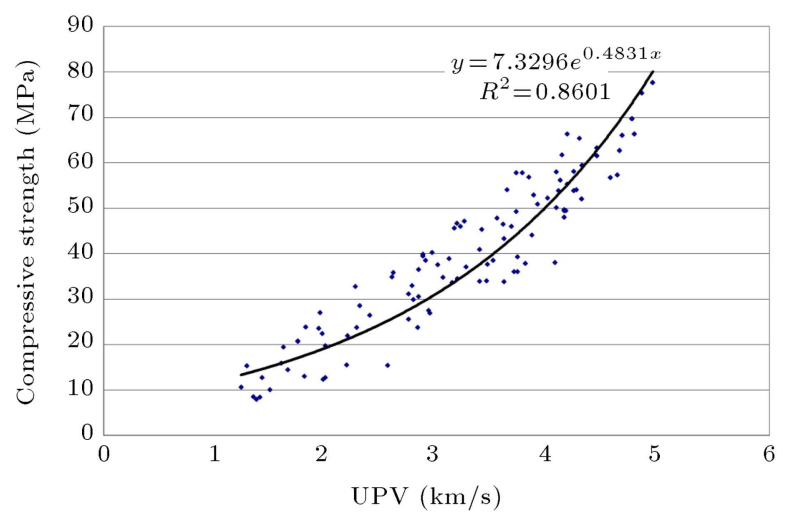

Figure 7. The relationship between compressive strength and UPV.

very good. In case $R^{2}=0.86$, it can be said that $86 \%$ of the variation in the compressive strength was calculated by the exponential relationship with ultrasonic pulse velocity (see Figure 7).

\section{Conclusion}

This paper focused on the effects of inadequate compaction on compressive strength when exposed to elevated temperature. In this study, the Taguchi method was used to reduce the required number of samples. ANOVA was applied to the experimental data to determine efficiency. According to ANOVA, the most effective factor on compressive strength of specimens was $w / c$ ratio. The effect of inadequate compaction on compressive strength increased with increase in temperature. At all temperatures, the maximum compressive strength was observed in samples with 0.35 water-cement ratio with vibration compaction. The effect of compaction on compressive strength was $48 \%$ at $900^{\circ} \mathrm{C}$, while it was $6 \%$ at $20^{\circ} \mathrm{C}$. The Taguchi approach was successfully used to determine the physical and mechanical properties of different compacted concretes in this study. The findings in this study may be very useful for determining mechanical and physical properties of an actual application. Furthermore, in this study, it was determined that the relationship between UPV and compressive strength was high.

\section{References}

1. Steffens, A., Dinkler, D. and Ahrens, H. "Modelling carbonation for corrosion risk prediction of concrete structures", Cement and Concrete Research, 32(6), pp. 935-941 (2002).

2. CEB (Comite Euro-International du Beton) Design Guide, Durable Concrete Structures, Lausanne: Thomas Telford Ltd (1992).

3. CEB\&RILEM International Workshop, "Durability of 
concrete structures", Workshop Report, edited by Rostam S. Copenhagen (1983).

4. Soroka, I., Portland Cement Paste and Concrete, London: Macmillan (1979).

5. Mehta, P.K., Concrete: Structure, Properties and Materials, New York: Prentice-Hall (1986).

6. Neville, A.M. and Brooks, J.J., Concrete Technology, Singapore: Longman (1990).

7. Brandt, A.M. "Cement based composites: materials", Mechanical Properties and Performance, London: E \& FN Spon (1995).

8. Newman, K. "Concrete systems", in: L. Holliday (Ed.), Composite Materials, Elsevier, USA, pp. 336352 (1966).

9. Gonen, T. and Yazicioglu, S. "The influence of compaction pores on sorptivity and carbonation of concrete", Construction and Building Materials, 21(5), pp. 1040-1045 (2007).

10. Demirel, B. and Kelestemur, O. "Effect of elevated temperature on the mechanical properties of concrete produced with finely ground pumice and silica fume", Fire Safety Journal, 45, pp. 385-391 (2010).

11. Türkmen, I. and Findık, S.B., Several Properties of Mineral Admixtured Lightweight Mortars at Elevated Temperatures Fire and Materials, 37(5), pp. 337-349 (2010).

12. Furumura, F., Abe, T. and Shinohara, Y. "Mechanical properties of high strength concrete at high temperatures", Proceedings of the Fourth Weimar Workshop on High Performance Concrete: Material Properties and Design, Weimar, Germany, Oct. pp. 237-254 (1995).

13. Tarun, R.N. and Rudolph, N.K. "Temperature effects on high-performance concrete", 6th International Symposium on Utilization of High Strength/High Performance Concrete (2002).

14. Uygunoglu, T. and Tobcu, I.B. "Effect of aggregate type on linear thermal expansion of self-consolidating concrete at elevated temperatures", Science And Engineering of Composite Materials, 19, pp. 259-269 (2012).

15. Poon, C.S., Azhar, S., Anson, M. and Wong, Y.L. "Comparison of the strength and durability performance of normal and high-strength pozzolanic concretes at elevated temperatures", Cement and Concrete Research, 31(9), pp. 1291-1300 (2001).

16. Poon, C.S., Shui, Z.H. and Lam, L. "Compressive behavior of fiber reinforced high-performance concrete subjected to elevated temperatures", Cement and Concrete Research, 34, pp. 2215-2222 (2004).

17. Chan, Y.N., Luo, X. and Sun, W. "Compressive strength and pore structure of high-performance concrete after exposure to high temperature up to $800^{\circ} \mathrm{C}$ ", Cement and Concrete Research, 30, pp. 247-251 (2000).
18. TS EN 197-1, Cement- Part 1: Composition Sand Conformity Criteria for Common Cements, Turkish Standards Institution, Turkey (2002).

19. Nian, C.Y., Yang, W.H. and Tarng, Y.S. "Optimization of turning operations with multiple performance characteristics", Journal of Materials Processing Technology, 95, pp. 90-96 (1999).

20. Ranjit, R., A Primer on the Taguchi Method, New York: Van Nostrand Reinhold (1990).

21. Türkmen, I., Gül, R. and Çelik, C.A. "Taguchi approach for investigation of some physical properties of concrete produced from mineral admixtures", 43(6), pp. $1127-1137$ (2008).

22. Nuruddin, M.F. and Bayuaji, R. "Application of Taguchi's approach in the optimization of mix proportion for microwave incinerated rice husk ash foamed concrete", International Journal of Civil \& Environmental Engineering, 09(09), pp.121-29 (2009).

23. Kelestemur, O., Arıcı, E., Yıldız, S. and Gökçer, B. "Performance evaluation of cement mortars containing marble dust and glass fiber exposed to high temperature by using Taguchi method", Construction and Building Materials, 60, pp. 17-24 (2014).

24. Irdemez, S., Yildiz, Y.S. and Tosunoglu, V. "Optimization of phosphate removal from wastewater by electrocoagulation with aluminum plate electrodes", Separation and Purification Technology, 52(2), pp. 394-401 (2006).

25. Papadakis, V.G., Fardis, M.N. and Veyenas, C.G. "Hydration and carbonation of pozzolonic cements", ACI Mater. J. Technical Paper, 89(2), pp. 119-130 (1992).

26. Cabrera, J.G. and Lynsdale, C.J. "A new gas parameter for measuring the permeability of mortar and concrete", Magazine Concrete Research, 40, pp. 177182 (1988).

27. Rossignolo, J.A. and Agnesini, M.V. "Durability of polymer-modified lightweight aggregate concrete", $\mathrm{Ce}$ ment Concrete Comp., pp. 375-380 (2004).

28. Mohamedbhai, G.T.G. "Effect of exposure time and rates of heating and cooling on residual strength of heated concrete", Magazine Concrete Research, 38, pp. 151-158 (1986).

29. Ahmet, B., Kizilkanat, A.B., Yüzer, N. and Kabay, N. "Thermo-physical properties of concrete exposed to high temperature", Construction and Building Materials, 45, pp. 157-161 (2013).

30. Turkmen, I. "Influence of different curing conditions on the physical and mechanical properties of concretes with admixtures of silica fume and blast furnace slag", Materials Letter, 57, pp. 4560-4569 (2003).

31. Bhanja, S. and Sengupta, B. "Investigations on the compressive strength of silica fume concrete using statistical methods", Cem. Concr. Res., 32, pp. 13911394 (2002). 
32. Elices, M. and Rocco, C.G. "Effect of aggregate size on the fracture and mechanical properties of a simple concrete", Engineering Fracture Mechanics, 75(13) pp. 3839-3351 (2008).

33. Rocco, C.G. and Elices, M. "Effect of aggregate shape on the mechanical properties of a simple concrete", Engineering Fracture Mechanics, 76(2), pp. 286-298 (2009).

34. Sarshar, R. and Khoury, G.A. "Material and environmental factors influencing the compressive strength of unsealed cement paste and concrete at high temperatures", Mag. Concr. Res., 45, pp. 51-61 (1993).

35. Chan, Y.N., Peng, G.F. and Anson, M. "Spalling mechanism and fire resistance of high performance silica fume concrete with different moisture content", Proc. of the 4 th Beijing Inter. Symp. of Cem. and Concr., Beijing, China, pp. 149-153 (1998).

36. Ulucan, Z.Ç., Turk, K. and Karatas, M. "Effect of mineral admixtures on the correlation between ultrasonic velocity and compressive strength for self-compacting concrete", Russian Journal of Nondestructive Testing, 44(5), pp. 367-374 (2008).

37. Gul, R., Demirboga, R. and Guvercin, T. "Compressive strength and ultrasound pulse velocity of mineral admixtured mortars", Indian Journal of Engineering \& Materials Sciences, 13, pp. 18-24 (2006).

38. Turgut, P. "Research into the correlation between concrete strength and UPV values", NDT.net. 12:12 (2004).
39. Nilsen, A. and Aitcin, P. "Static modulus of elasticity of high strength concrete from pulse velocity tests", Cem. Concr. Aggr., 14(1), pp. 64-66 (1992).

40. Phoon, K.K., Wee, T.H. and Loi, C.S. "Development of statistical quality assurance criterion for concrete using ultrasonic pulse velocity method", ACI Material Journal, 96(5), pp. 568-573 (1999).

41. Tharmaratram, K. and Tan, B.S. "Attenuation of ultrasonic pulse in cement mortar", Cem. Concr. Res., 20, pp. 33-340 (1990).

42. Cho, Y.S., Kim, J.H. and Hong, S.U. "Compressive strength prediction of porous concrete using nondestructive tests", Journal of Civil Engineering and Architecture, 5(12), pp. 1053-1064 (2011).

43. Prasopchaichana, K. "Evaluating the compressive strength of concrete exposed to elevated temperatures using ultrasonic pulse velocity and artificial neural networks", 6th European Workshop on Structural Health Monitoring - Poster, 17 (2012).

\section{Biography}

Tahir Gonen received his $\mathrm{PhD}$ degree in Construction Education from Firat University, Turkey, in 2009, and is currently Assistant Professor in the Civil Engineering Department, Construction Materials Division, Usak University, Turkey. His main research interests include different concrete design, durability, and mechanical properties. 